\title{
Stony Brook's Collaborations with Czech Scientists
}

\author{
Robert Cooper Liebermann \\ Mineral Physics Institute and Department of Geosciences, Stony Brook University, NY, USA \\ Email: Robert.Liebermann@stonybrook.edu
}

How to cite this paper: Liebermann, R.C. (2021) Stony Brook's Collaborations with Czech Scientists. International Journal of Geosciences, 12, 487-498.

https://doi.org/10.4236/ijg.2021.125026

Received: April 27, 2021

Accepted: May 23, 2021

Published: May 26, 2021

Copyright $\odot 2021$ by author(s) and Scientific Research Publishing Inc. This work is licensed under the Creative Commons Attribution International License (CC BY 4.0).

http://creativecommons.org/licenses/by/4.0/

\begin{abstract}
For the past half-century, I have been fortunate in maintaining collaborations with Czech scientists in the Czech Republic [formerly Czechoslovakia] from the Geofyzikální ústav-GFU [Institute of Geophysics] of the Československá Akademie Věd-ČSAV [Czechoslovak Academy of Sciences]. These collaborations have included exchange visits by me to Prague [Praha] and convening international workshops in 1976, 1986 and 1996 in castles used by the ČSAV as well as visits by Czech colleagues to Stony Brook University. The objective of this report is to relate this history. This paper is dedicated to the memory of Vladislav Babuška.
\end{abstract}

\section{Keywords}

Mineral Physics, High Pressure, High Temperature, Anisotropy and Lateral Heterogeneity of the Earth's Mantle

\section{Introduction}

Over the past decade, I have written papers on my history pursuing a scientific career in mineral physics. The first 3 of these papers appeared in a Special Issue of the journal Minerals and were later included in the book volume on "Mineral Physics: In Memory of Orson Anderson": these included "The Orson Anderson era of mineral physics at Lamont in the 1960s" [1]; "The birth of mineral physics at the ANU in the 1970s" [2]; "My career as a mineral physicist at Stony Brook: 1976-2019" [3]; and "Bob-san and high-pressure science and technology in Japan: A 40-year history" [4]. More recently, I have also published a paper on "Stony Brook's high-pressure laboratory collaborations with French scientists" in the International Journal of Geosciences [5].

This new paper is of a similar genre. 
My acquaintance with Czech geophysics began at the 1967 Congress of the International Union of Geodesy and Geophysics [IUGG] in Zurich, Switzerland, where I met Vít Kárník and Jiří Vaněk from the Geofyzikální ústav-GFU [Institute of Geophysics] of the Československá Akademie Věd [Czechoslovak Academy of Sciences ČSAV] in Prague. They encouraged me to visit their Institute sometime for collaborative research. In 1969, Vladislav Babuška visited the Mineral Physics Laboratory at Lamont Geological Observatory while he was a Research Fellow in Francis Birch's laboratory at Harvard University; my advisor Orson Anderson asked me to be his guide during this visit.

Over the next 50 years, I have developed strong connections with scientists in the Czech Republic. These connections have included exchange visits by me to Prague [Praha] and convening a series of international workshops in 1976, 1986 and 1996, as well as visits by Czech colleagues to Stony Brook University.

\section{Exchange Visit to GFU-CSAV in 1971}

In 1971 after the IUGG General Assembly in Moscow, I had the privilege of visiting geophysical institutes in Czechoslovakia on a scientific exchange program sponsored by the United States National Academy of Sciences and the Czechoslovak Academy of Sciences [ČSAV]. The purpose of this visit was to observe current geophysical research in Czechoslovakia, to become acquainted with research scientists in this field, and to exchange ideas and expertise with them. Under the terms of the exchange agreement, the U.S. Academy provided support for my transport to Czechoslovakia and the ČSAV provided subsistence and travel expenses within the country; I stayed at the Botel Racek on the Vltava River.

The principal focus of my visit was the GFU in Prague, the largest and most active center for geophysical research in the country. In particular, I spent most of my time discussing mutual research interests with the seismology and mineral physics groups in that institute. I spent six weeks at the GFU working with Zdeněk Pros and Vladislav [hereafter Vlád’a] Babuška on measurements of elastic anisotropy to study the velocities of natural rocks using a novel technique to fabricate spherical specimens [see Pros and Babuška [6]; Pros et al. [7]].

I also met many of their colleagues, including Jaroslava [hereafter Jarka] Plomerová who was then a graduate student in seismology and advised by Jiří Vaněk.

Babuška has had a pioneering role in the study of seismic anisotropy, from laboratory experiments of elastic anisotropy of rock samples with Zdeněk Pros through seismic anisotropy of the Earth's crustal and mantle structures on continental and global scales with Jaroslava Plomerová that is recognized worldwide [see Babuška, Plomerová and Šílený [8]; Plomerová, Śílený and Babuška [9]].

I also had considerable interaction with the Department of Geophysics of Charles University in Prague. Brief visits were made to the Institute of Applied Geophysics in Brno and the Geophysical Institute of the Slovak Academy of Sciences in Bratislava.

Geophysical and geological field excursions provided opportunities to see re- 
mote seismic stations, to collect Moldavian tektites [near Kaplice] and ultrabasic rocks of the Bohemian Massif, to visit the famous ore mines and mining museum in Př́bram, and observe the karst topography in Moravia [Macocha]. My hosts also took considerable pains to ensure that I did not omit any of the cultural attractions of their beautiful country; particularly memorable were the churches, pivní hospody (beer pubs) and vinárny (wine restaurants) of Prague, the spas of Karlovy Vary [Carlsbad] and Mariánské Lázně [Marienbad], the castles and towns of southern Bohemia [especially Český Krumlov and České Budějovice, the ossuary of Kutná Hora, the wine cellars of southern Moravia, the Town Hall in Levoča, and the majestic High Tatras near Skalnaté Pleso in Slovakia. All of these excursions were funded by the ČSAV and led by colleagues from the GFU, especially Zdeněk Pros (Figure 1).

Although I developed a 300-word vocabulary during the month, I spoke no Czech when I arrived in Prague. Communication was not inhibited, however, since most of my fellow scientists spoke English well and pencil sketches filled in the gaps. Students, in particular, were anxious for the contact with a native English speaker; and during walks in the woods, young children would teach me the name of the trees: bríza for birch [which surprised some of my geophysical colleagues who knew the name Birch in a different context]. German proved useful when dealing with shop keepers, tram conductors and hotel staff. Travel throughout the country was completely unrestricted and easy, although a substantial reason for this ease in my case was the unselfish and attentive guidance of my traveling companions.

As noted above, my exchange visit was in August and September 1971, three years after Alexander Dubček introduced the reforms of the Prague Spring [a period of political liberalization and mass protest in the Czechoslovak Socialist Republic]. In August 1968, the Soviet Union and other Warsaw Pact members invaded the country to suppress the reforms. During my visit, it was still possible to see bullet holes in the National Museum at the top of Václavské náměstí [Wenceslas Square] and the damage to the statue of national patron St. Wenceslas (Figure 2).

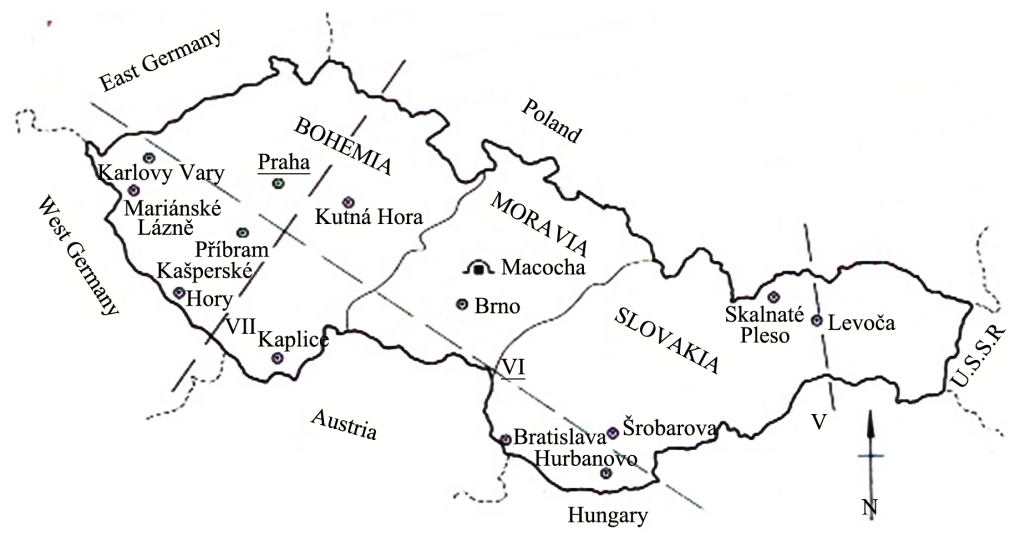

Figure 1. Map of Czechoslovakia in 1971 showing sites of field excursions. Translation: Praha-Prague; Karlovy Vary-Carlsbad; Mariánské Lázně-Marienbad. 


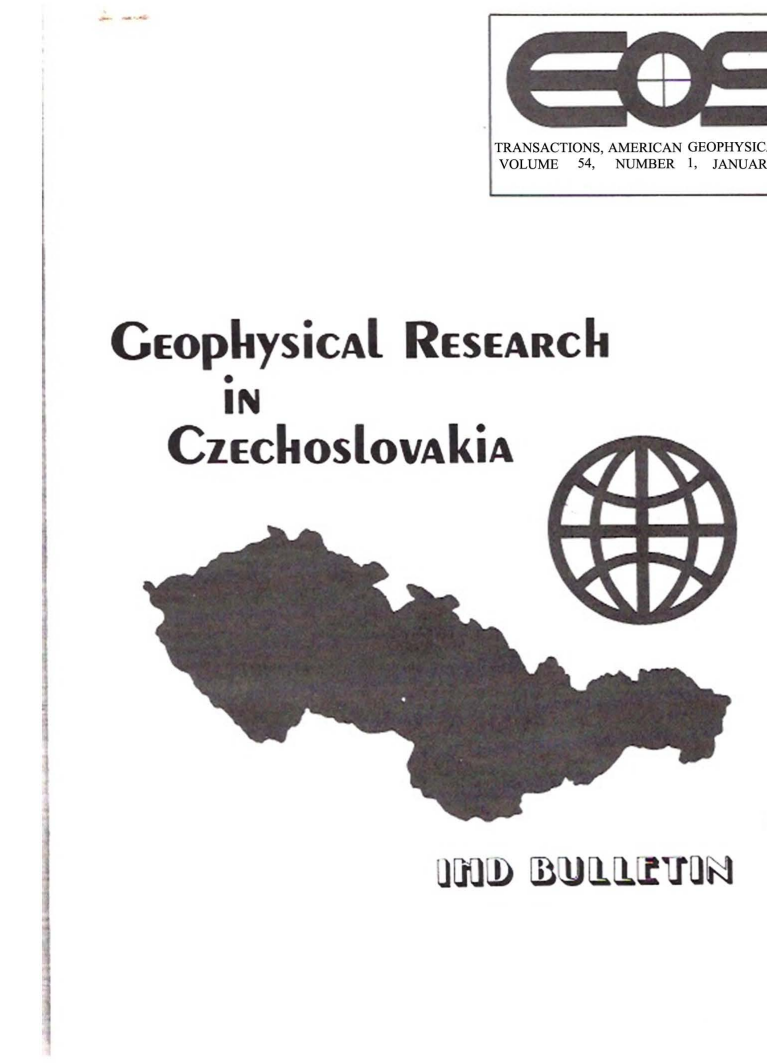

Figure 2. A report on this visit was published in Transactions, American Geophysical Union in 1973 [10].

\section{International Workshops}

At the 1973 meeting of the International Association of Seismology and Physics of the Earth's Interior [IASPEI] in Lima, Peru, Charles Drake encouraged me to organize a workshop in Eastern Europe, so that young scientists from countries in the Eastern Bloc could attend. Vláda, Jarka, Vlastislav Červený and I convened the first of these workshops in 1976 at the Castle of Liblice in central Bohemia on "Anisotropy and Heterogeneity of the Lithosphere" (Babuška and Liebermann [11]). Using the 1976 model, we convened two other meetings in 1986 at the Castle of Bechyně and in 1996 at the Chateau of Třešt.

The main objectives of this workshop series we started to organize in 1976 was to bring together geoscientists-geophysicists, geochemists, mineral and rock physicists, geologists-to evaluate various techniques of many geoscience disciplines for mapping/modelling the inner structure of the Earth, to jointly interpret results from different datasets aiming at reducing the family of plausible models and to be able to understand development of the Earth in the past.

Of particular interest were:

1) Relation of the large-scale seismic anisotropy to the strain-induced preferred orientation of crystals (especially olivine in the mantle) provides a perspective by which seismic anisotropy, along with other disciplines, contributes to a better knowledge of the Earth. 
2) Relation between seismic anisotropy and geodynamic processes, long-term memory of structures (fabrics) vs. plastic deformations and structural reorganization in different regions of the Earth are subjects of these workshops as well.

In the following sections, the major topics of the three workshops are listed.

1) Anisotropy and Heterogeneity of the Lithosphere at Castle of Liblice, Czechoslovakia, June 1976

Conveners: V. Babuška, J. Plomerová, V. Červený and R.C. Liebermann. Sponsored by the GFU of the ČSAV (Figure 3 and Figure 4).

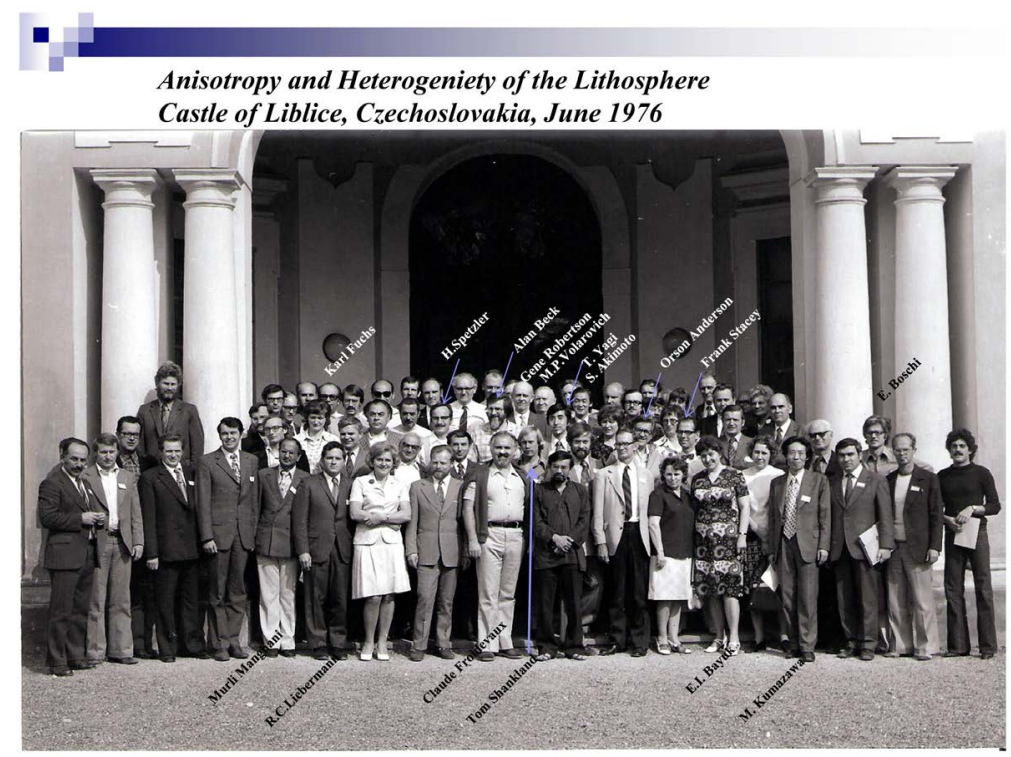

Figure 3. Attended by 75 scientists from 12 countries. Additional IDs: Vláda is on Murli Manghnani's right, Jarka is just behind Liebermann, Zdeněk Pros is on Frank Stacey's left. Jiři Vaněk is to the right and behind Alan Beck.

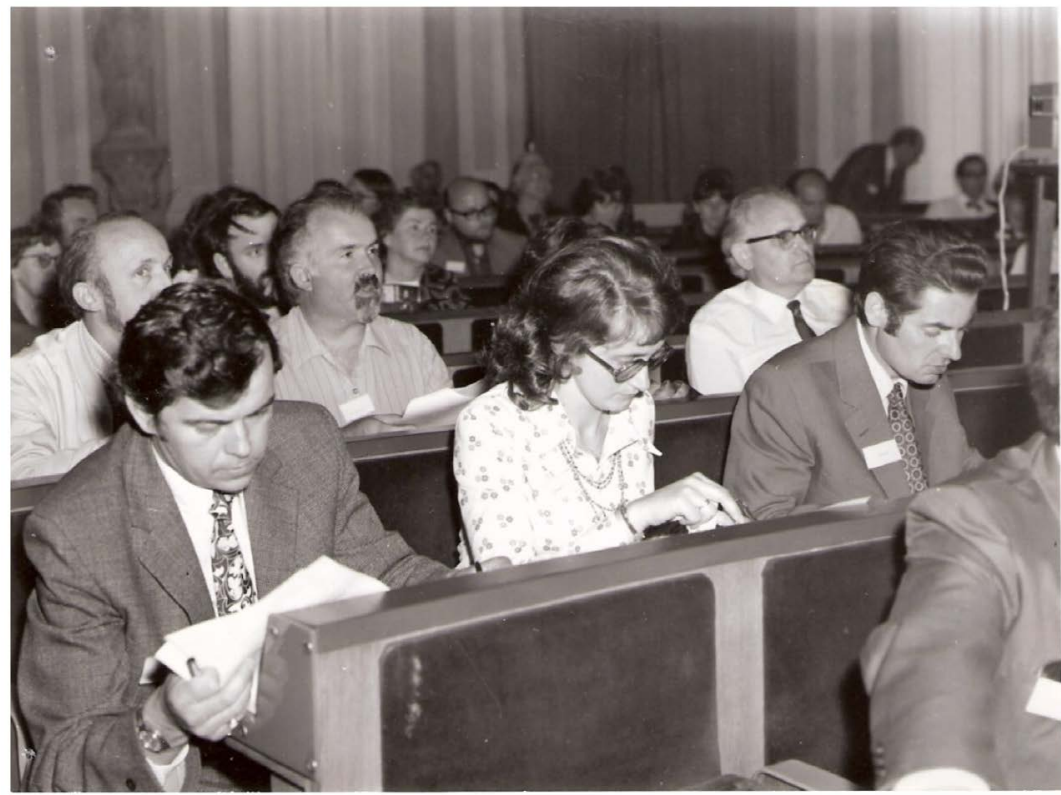

Figure 4. Vlád’a, Jarka and Milan Krešl in front row from left. Jiří Vaněk behind Krešl. 
The main topics discussed were:

Physical properties of minerals and rocks at high pressure and temperature;

Anisotropy of Earth materials at different scales;

Large-scale anisotropy vs. heterogeneity in the upper mantle;

Dynamic processes in the lithosphere-asthenosphere system;

Theory of seismic wave propagation.

57 papers were presented in sessions designated as:

Equations of state;

Magnetic, electrical and thermal properties;

Phase transformations;

Elastic properties and Earth models;

Anisotropy and preferred orientation;

Flow and fracture.

See details in Babuška and Liebermann [11] in EOS, Transactions, American Geophysical Union, Vol. 58, no. 3, 156-159, 1977 (Figures 5-8).

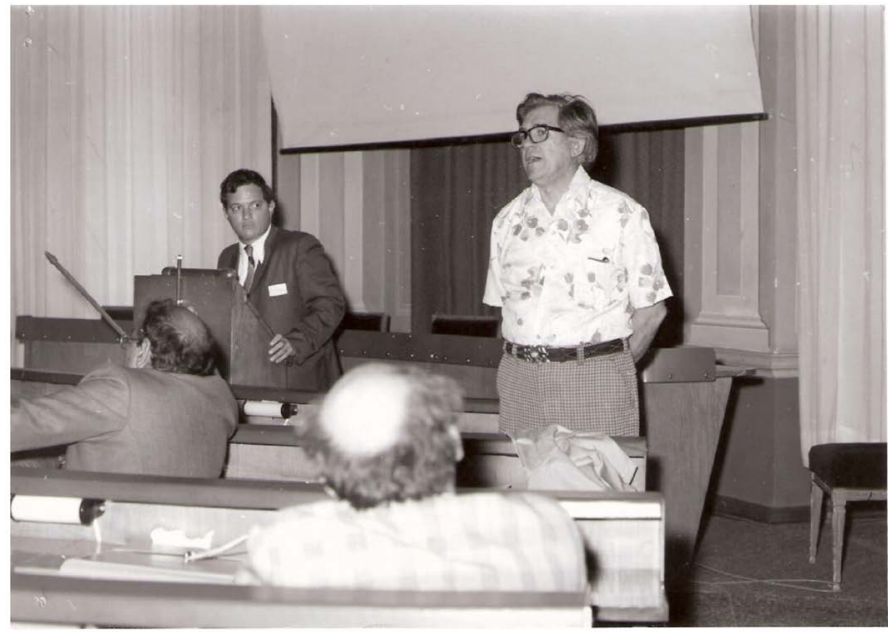

Figure 5. Bob Liebermann introducing his Ph.D. advisor Orson Anderson at Liblice.

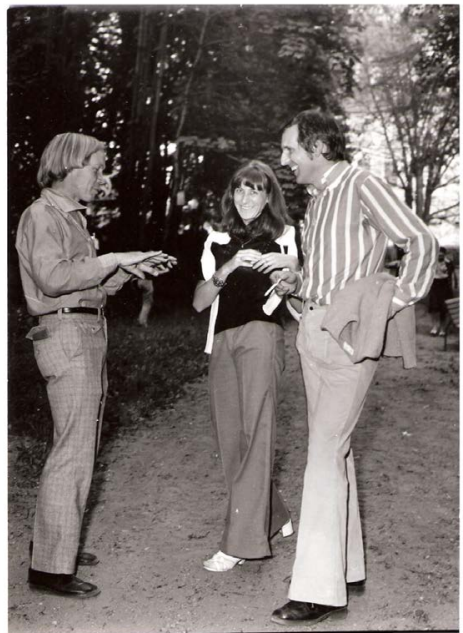

Figure 6. Thomas Shankland with Marcela Laštovičková and Vladimír Čermák at Liblice. 


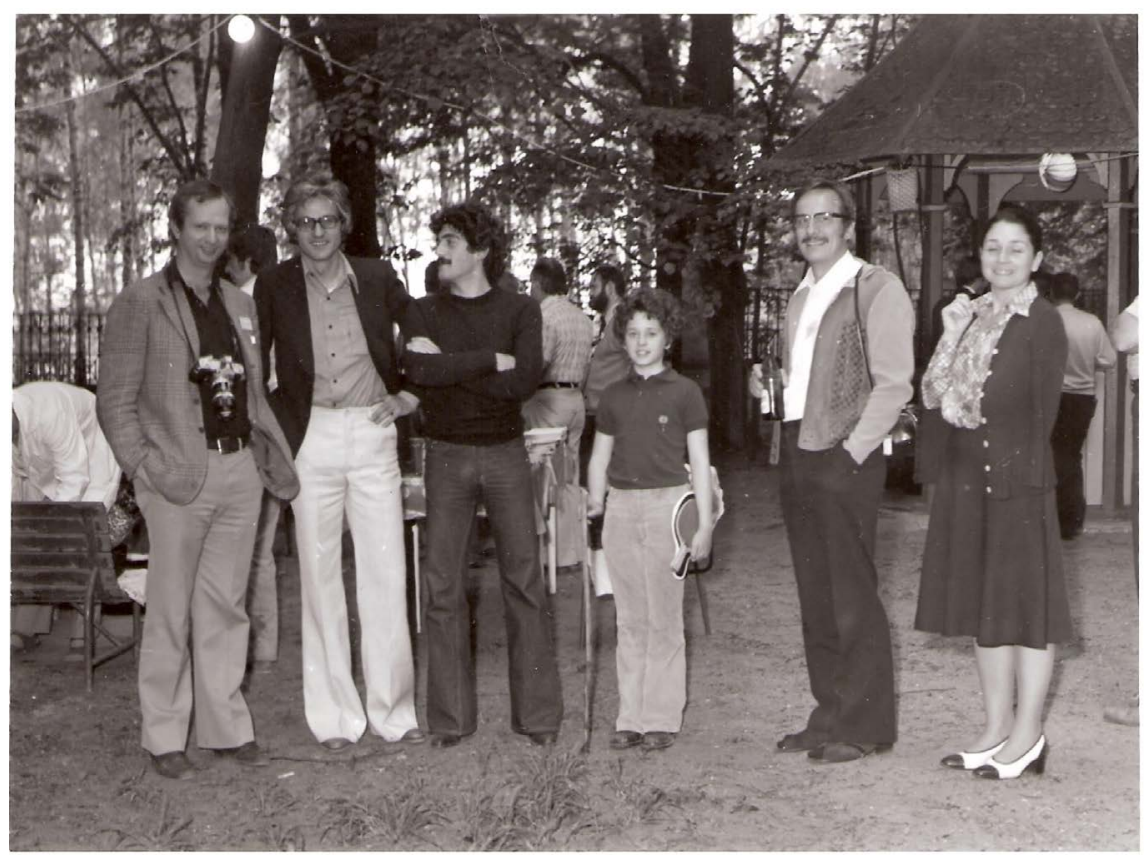

Figure 7. Richard O’Connell, Enzo Boschi, Francesco Mulargia, Brian O’Connell, Hartmut Spetzler, Micheline O'Connell at Liblice.

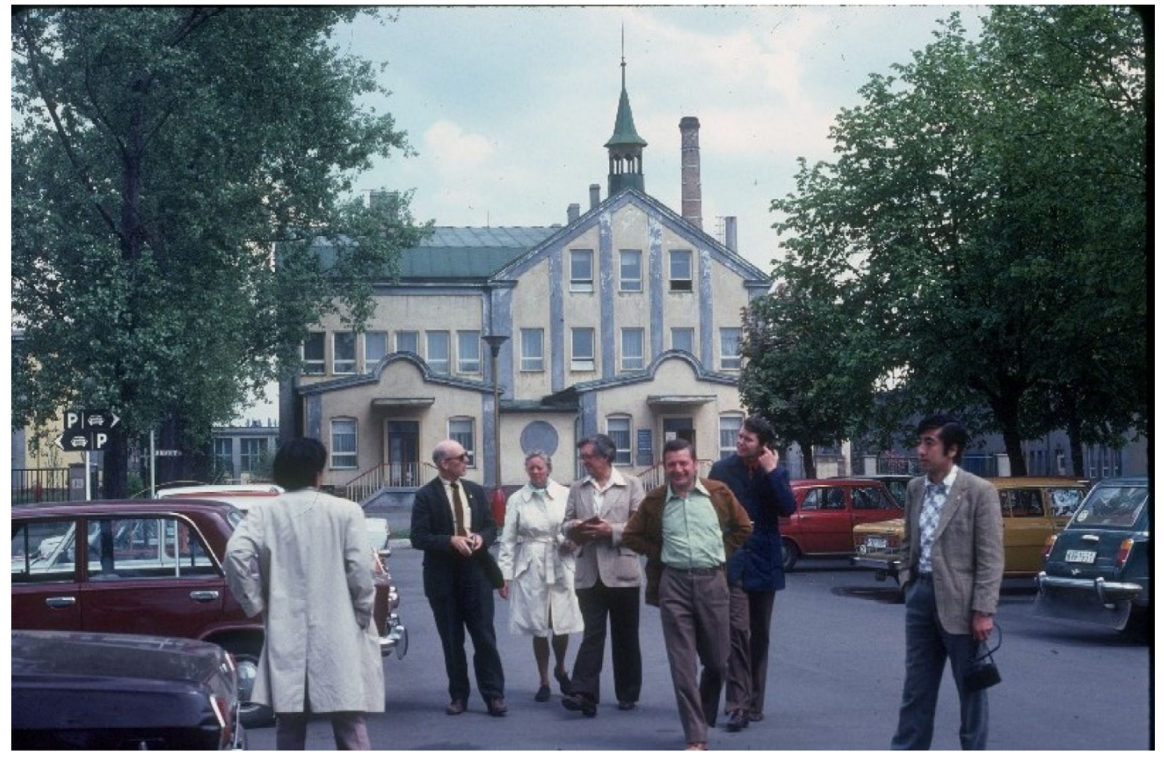

Figure 8. "Field trip" during the Liblice workshop to the Moser crystal factory in Karlovy Vary [Carlsbad]. L. to R. Mineo Kumazawa, Eugene Robertson and his wife, Orson Anderson, Zdeněk Pros, Vladislav Babuška, and Takehiko Yagi.

\section{2) Anisotropy and Inhomogeneity of the Lithosphere and Asthenosphere} at Castle of Bechyné, Czechoslovakia, September 1986

Conveners: V. Babuška, J. Plomerová, L. Waniek and R.C. Liebermann

Sponsored by the UNESCO Division of Earth Sciences, the Inter-Union Commission on the Lithosphere (ICL) and the International Association of Seismology and Physics of the Earth's Interior (IASPEI) (Figure 9 and Figure 10). 
Anisotropy and Inhomogeneity of Lithosphere and Asthenosphere Castle of Bechynĕ, Czechoslovakia, 8-13 September 1986

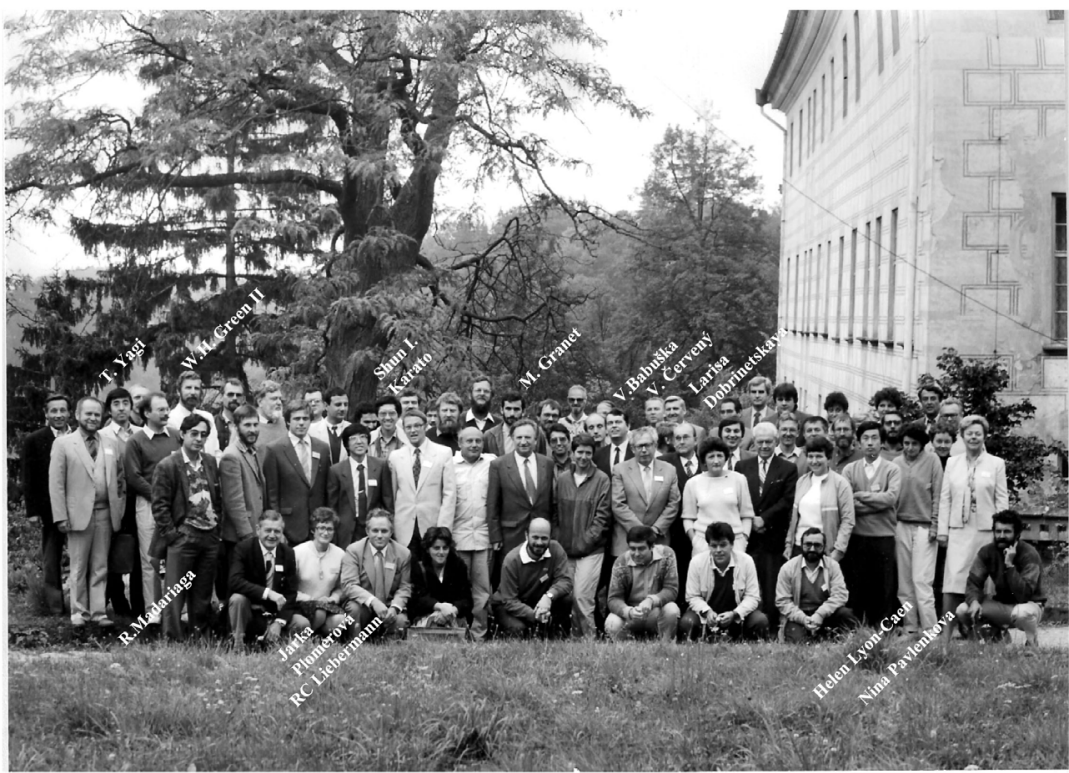

Figure 9. Workshop participants at Bechyně in September 1986. Attended by 76 scientists from 14 countries. Additional IDs: Zdeněk Pros to right of Jarka. Larissa Dobrzinetskaya on Ludwik Waniek's right.

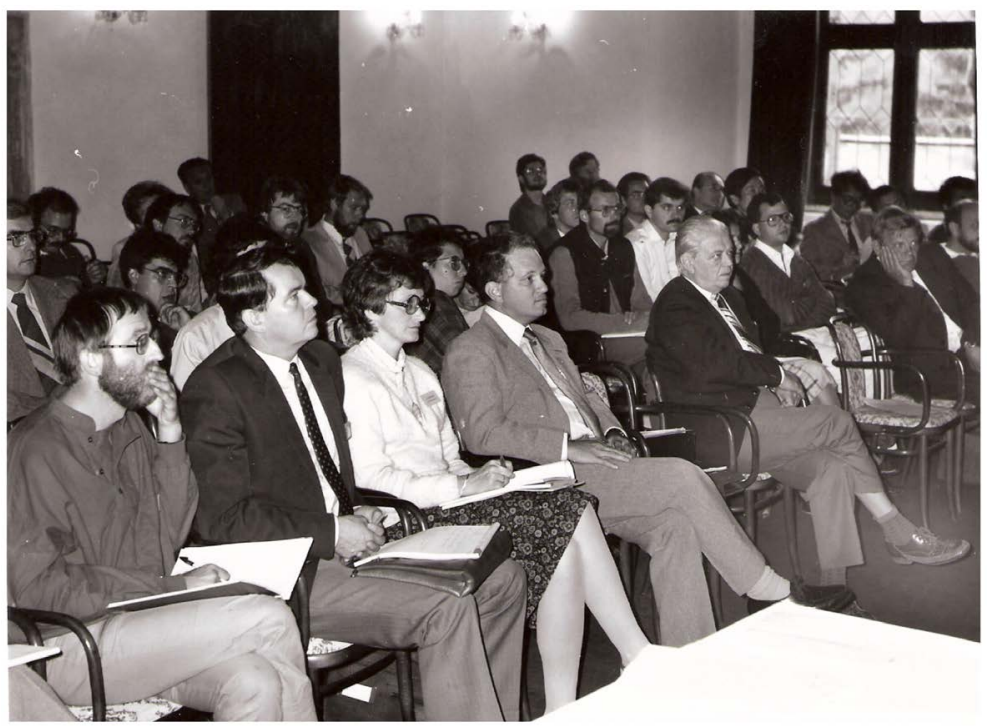

Figure 10. L. to R. Unidentified, Vláda, Jarka, Bob and Ludwik Waniek at Bechyně workshop.

The main topics were:

Generation and propagation of seismic waves within anisotropic and inhomogeneous media;

Three-dimensional mapping of the lithosphere and asthenosphere;

Experimental data and their interpretation-rheology, petrology, mineral physics. 
34 contributions of the 57 presented in the workshop were published in a volume edited by Babuška, Plomerová, Červený and Liebermann [12] in Physics of the Earth and Planetary Interiors, Vol. 51, 248 pp., 1988 (Figure 11).

\section{3) Geodynamics of Lithosphere and Earth's}

Mantle: Seismic Anisotropy as a Record of the Past and Present Dynamic Processes at the Chateau of Třešt, Czech Republic, June 1996

Conveners: J. Plomerová, V. Babuška and R.C. Liebermann.

Sponsored by the GFU of the Czech Academy of Sciences in Prague and CHiPRNSF Center for High Pressure Research at Stony Brook University (Figure 12).

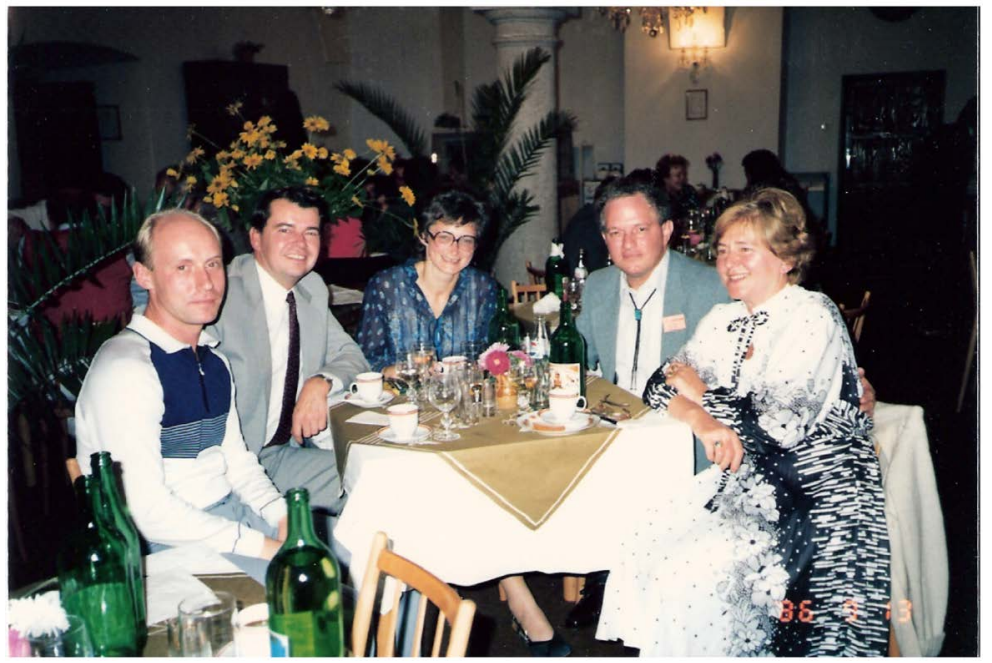

Figure 11. Dinner at U Zlatého Jelena to thank the staff who organized the logistics for the workshop. L. to R. Unidentified, Vláda, Jarka and Bob with Hana Procházková, who managed the financial affairs for all the workshops.

Geodynamics of Lithosphere and Earth's Mantle: Seismic Anisotropy as a Record of the Past and Present Dynamic Processes

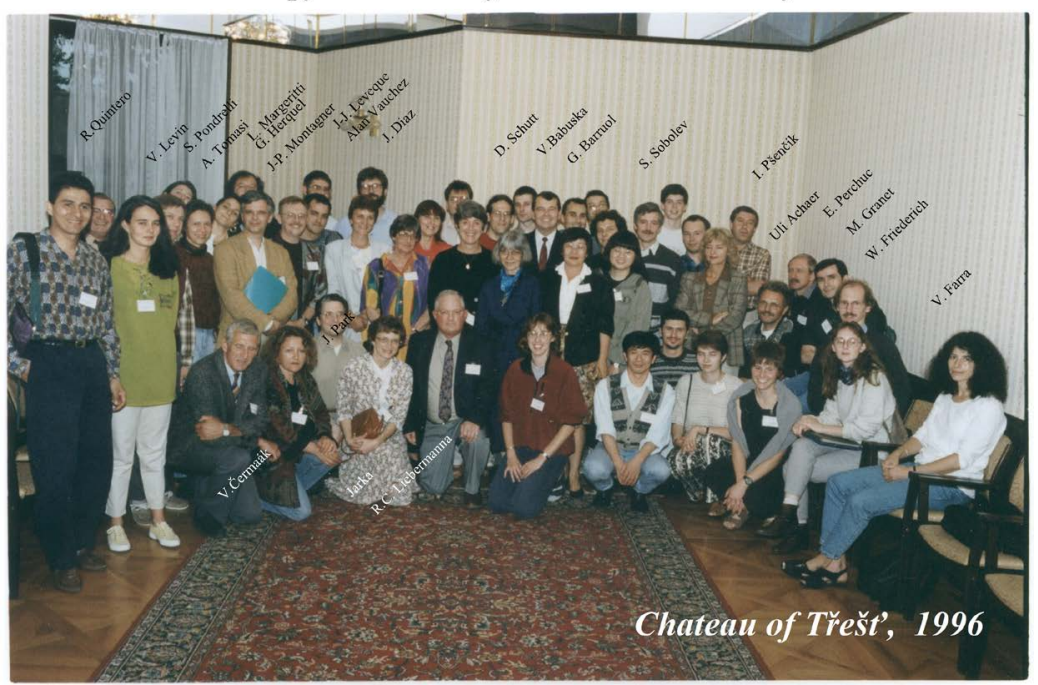

Figure 12. Workshop participants at Třešt in June 1996. Additional IDs: Barbara Liebermann in back of Bob, Veronika Vajdová in first row, third from right, Jan Plomer to left of Stephen Sobolev. 
The main topics of this workshop were:

Large-scale Anisotropy of the Earth' Mantle;

Mantle Heterogeneities vs. Anisotropy: 3D Velocity and Density Structures and Inferences on Mantle Dynamics;

Mineral and Rock Physics Studies;

Mathematical Aspects of Complex Wave Propagation and their Applications.

26 contributions of the 67 presented in the workshop were published in a volume edited by Plomerová, Liebermann and Babuška [13] in Pure and Appl. Geophys. Vol. 151, 718 pp., 1998 and entitled:

Geodynamics of Lithosphere \& Earth's Mantle;

"Seismic Anisotropy as a Record of the Past and Present Dynamic Processes".

\section{Conclusion}

In subsequent years, I have maintained this connection to my colleagues in Prague via visits to the GFU, meeting at conferences in Europe and North America and visits by Vláda and Jarka to Stony Brook. I would like to dedicate this paper to my dear friend and colleague Vladislav Babuška, who died on March 30, 2021.

(Figure 13)

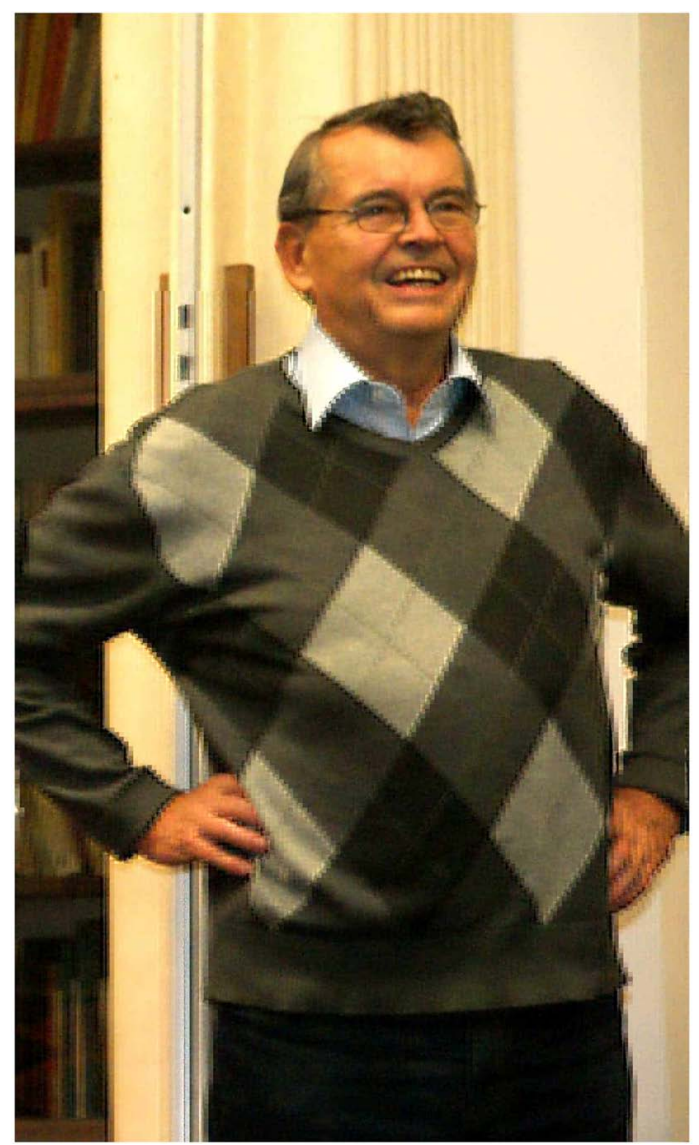

Figure 13. 2012: Vláda Babuška at the 60th birthday of Jan Šílený. A tribute to Vláda by Jan may be found on the AGU In Memoriam website at https://www.agu.org/Stay-Informed/In-Memoriam. 


\section{Acknowledgements}

I am grateful to my colleague Jarka Plomerová for providing me with a review of the workshop series that she presented at an ADLAS (Anisotropy and Dynamics of the Lithosphere-Asthenosphere System) workshop in 2016 in Prague, and for substantial contributions and editing of early versions of the paper. I also thank Peter Molnar and Takehiko Yagi for reminding me of some details of my visits to Czechoslovakia in the 1970s and 1980s, and Jan Šílený for the photo of Vlád’a. I have profited from the comments and suggestions of five reviewers [including P. Molnar, T. Shankland and T. Yagi] whose comments and suggestions have markedly improved the paper. My collaborations with Czech colleagues have been supported by research grants from the NSF as well as international grants from the Czechoslovak Academy of Sciences and the U.S. National Academy of Sciences. This report was written with support from a research grant to Baosheng Li and me from the National Science Foundation (EAR-1524078).

\section{Conflicts of Interest}

The author declares no conflicts of interest regarding the publication of this paper.

\section{References}

[1] Liebermann, R.C. (2019) The Orson Anderson Era of Mineral Physics at Lamont in the 1960s. Minerals, Mineral Physics. In memory of Orson Anderson, 9, Article No. 342. https://doi.org/10.3390/min9060342

[2] Liebermann, R.C. (2020) The Birth of Mineral Physics at the ANU in the 1970s. Minerals, Mineral Physics. In memory of Orson Anderson, 10, Article No. 163. https://doi.org/10.3390/min10020163

[3] Liebermann, R.C. (2019) My Career as a Mineral Physicist at Stony Brook: 1976-2019. Minerals, Mineral Physics: In memory of Orson Anderson, 9, Article No. 761. https://doi.org/10.3390/min9120761

[4] Liebermann, R.C. (2011) Bob-San and High Pressure Science Technology in Japan: A 40+-Year History. Review of High Pressure Science and Technology, 21, 115-126. https://doi.org/10.4131/jshpreview.21.115

[5] Liebermann, R.C. (2021) Stony Brook's High-Pressure Laboratory Collaborations with French Scientists. International Journal of Geosciences, 12, 195-212. https://doi.org/10.4236/ijg.2021.123012

[6] Pros, Z., Lokajíček, T. and Klíma, K. (1998) Laboratory Approach to the Study of Elastic Anisotropy on Rock Samples. Pure and Applied Geophysics, 151, 619-629. https://doi.org/10.1007/978-3-0348-8777-9_22

[7] Pros, Z. and Babuška, V. (1968) An Apparatus for Investigating the Elastic Anisotropy on Spherical Samples. Studia Geophysica et Geodaetica, 12, 192-198. https://doi.org/10.1007/BF02587847

[8] Babuška, V., Plomerová, J. and Šílený, J. (1993) Models of Seismic Anisotropy in the Deep Lithosphere of Central Europe. Physics of the Earth and Planetary Interiors, 78, 167-191. https://doi.org/10.1016/0031-9201(93)90154-2

[9] Plomerová, J., Šílený, J. and Babuška, V. (1996) Joint Interpretation of Upper-Mantle 
Anisotropy Based on Teleseismic P-Travel Time Delay and Inversion of Shear-Wave Splitting Parameters. Physics of the Earth and Planetary Interiors, 95, 293-309. https://doi.org/10.1016/0031-9201(95)03122-7

[10] Liebermann, R.C. (1973) Geophysical Research in Czechoslovakia. Eos Transactions American Geophysical Union, 54, 4-17. https://doi.org/10.1029/EO054i001p00004

[11] Babuška, V. and Liebermann, R.C. (1977) Physical Properties of Upper Mantle Rocks in Relation to Geodynamic Processes. Eos Transactions American Geophysical Union, 58, 156-159. https://doi.org/10.1029/EO058i003p00156

[12] Babuška, V., Plomerová, J., Červený, V. and Liebermann, R.C. (1988) Physics of the Earth and Planetary Interiors-Preface. 51, vii.

[13] Plomerová, J., Liebermann, R.C. and Babuška, V. (1998) Geodynamics of Lithosphere \& Earth's Mantle: Seismic Anisotropy as a Record of the Past and Present Dynamic Processes. Pure and Applied Geophysics, 151, 213-219.

https://doi.org/10.1007/s000240050112 